\title{
SUATU KAJIAN TENTANG SOSIAL EKONOMI WARALABA / TOKO MODERN ( FOKUS KAJIAN DUA KECAMATAN TAROGONG KIDUL DAN KECAMATAN CILAWU KABUPATEN GARUT )
}

\author{
Oleh : \\ Jajang Sugiat \\ Program Studi Manajemen - STIE Yasa Anggana Garut \\ Email: jajangya@stieyasaanggana.ac.id \\ Dadang Syafarudin \\ Program Studi Manajemen - STIE Yasa Anggana Garut \\ Email: dadangsya@ stieyasaanggana.ac.id \\ DOI Artikel : https://doi.org/10.34308/eqien.v7i1.119
}

\begin{tabular}{l} 
Article Info \\
\hline Article History: \\
Received $10 \mathrm{Feb}-2020$ \\
Accepted $20 \mathrm{Feb}-2020$ \\
Available Online $28 \mathrm{Feb}-2020$
\end{tabular}

Keyword:

Garut Regency, service perspective, minimarkets and traditional markets, UMKM \begin{abstract}
The phenomenon of the development of modern stores in Garut Regency is quite dynamic along with the rate of population growth in Kab. Garut, as quoted by National Online Media http://nasional.republika.co.id Garut Regency Unlike other regions that stop the addition of minimarkets, Garut Regency actually increases the minimarket quota. This was done so that the minimarket in the sub-district would grow evenly. Previously, the minimarket quota in Garut was only 213 units according to the district head's Decree (SK) in 2013. Starting in December 2015, the quota was added to 98 units, but based on the Regent's Regulation (Perbup) Number 3 In 2016, there are rules that must be met, namely administrative requirements regarding the distance between minimarkets and traditional markets. In addition to distance, minimarket entrepreneurs must also establish partnerships with surrounding communities. Thus, creating a healthy market competition in the environment. Issuance of minimarket licenses also requires recommendations in the form of environmental studies, building permits (IMB) and a number of coordination with related agencies. Based on applicable regulations, the construction of a minimarket can only take place after the government has issued the permit. The addition of the minimarket quota is based on a study and technical calculation conducted by the Department of Industry and Trade (Disperindag) of Garut Regency. Some things that affect the increase in minimarket quota, including Garut Regency's area, population, and people's purchasing power also include the presence of traders / shops / small shops around it. Based on the results of our study from a service perspective, the general presence of Alfamart in the two locations (Tarogong and Cilawu districts) is already good, such as price fixing, store location, involvement of local labor and operating hours. But there are some things that need attention including; the partnership between Alfamart and UMKM in the surrounding areas has not yet been established, the completeness of supporting infrastructure facilities that are inadequate and the period of validity for the extension of operational licenses should be monitored to fulfill the conditions set back
\end{abstract}




\section{PENDAHULUAN}

Berdasarkan perhitungan Biro Pusat Statistik Tahun 2015 seperti dikutip dari data Dinas Kependudukan dan Pencatatan Sipil tahun 2014 (www.garutkab.go.id) disesuaikan dengan registrasi mutasi penduduk, jumlah penduduk Kabupaten Garut tercatat sebanyak 2.526.186 jiwa yang terdiri dari laki-laki 1.274.098, perempuan 1.252.088, dengan demikian sex ratio (Jumlah Laki-Laki/Jumlah Perempuan X 100) di Kabupaten Garut adalah sebesar Rata-rata 104,2.

Tahun 2016 Kondisi "Indeks Pembangunan Manusia" (IPM) Kabupaten Garut ternyata hingga kini masih pula bertengger pada posisi ke-25 dari 27 kabupaten/kota di Provinsi Jawa Barat, atawa berpoin 63,21. Angka tersebut, juga masih berselisih minus 6,29 poin dari IPM Jawa Barat 69,50 poin, dan minus 6,34 poin dari IPM nasional mencapai 69,55 poin.

Laju Pertumbuhan Ekonomi Kabupaten Garut Tahun 2013 mencapai 4,82\%, meningkat $0,21 \%$ dibanding tahun 2012 sebesar 4,61\%. Meskipun masih berada di bawah pencapaian Jawa Barat $(5,78 \%)$ maupun Nasional $(6,06 \%)$, dan berdasarkan PDRB maka Sektor Unggulan Perekonomian Kabupaten Garut : Pertanian $(44,59 \%)$, Perdagangan $(26,81 \%)$, Jasa $(10,32 \%)$ dan Industri $(7,57 \%)$. Perkembangan nilai minat investasi di Kabupaten Garut tahun 2013 berdasarkan IPPT, IMB, IL dan SIUP dengan kriteria investasi $\geq$ Rp.500.000.000 tercatat sebesar Rp. 775.548.981.534, atau meningkat sebesar 22\% dari tahun sebelumnya.

Kawasan Strategis Kabupaten Garut yang memiliki nilai strategis ekonomi yang berpengaruh terhadap pertumbuhan ekonomi di Kabupaten Garut, antara lain : Kawasan Perkotaan Garut, Kawasan Koridor Kedungora - Leles - Garut, Kawasan Perbatasan Bagian Utara (Balubur Limbangan - Malangbong), Kawasan Perbatasan Bagian Timur (Singajaya dan sekitarnya), Kawasan Perbatasan Bagian Barat (Caringin Cisewu - Talegong), Kawasan Agropolitan Cisurupan dan sekitarnya, Kawasan Minapolitan Tarogong Kaler - Sukawening - Pangatikan Sucinaraja - Wanaraja dan Karangpawitan dan Kawasan Koridor Jalan Lintas Jawa Barat Selatan.

Terkait dengan kegiatan usaha perdagangan yang merupakan salah satu cara manusia untuk memenuhi kebutuhan hidupnya yang beranekaragam. Aktivitas perdagangan atau jual beli dilakukan di pasar, Peraturan Presiden No. 112 Tahun 2007 menerangkan bahwa :

1) Pasar adalah area tempat jual beli barang dengan jumlah penjual lebih dari satu baik yang disebut sebagai pusat perbelanjaan, pasar tradisional, pertokoan, mall, plasa, pusat perdagangan maupun sebutan lainnya.

2) Pasar adalah area tempat jual beli barang dengan jumlah penjual lebih dari satu baik yang disebut sebagai pusat perbelanjaan, pasar tradisional, pertokoan, mall, plasa, pusat perdagangan maupun sebutan lainnya;

3) Pasar Tradisional adalah pasar yang dibangun dan dikelola oleh Pemerintah, Pemerintah Daerah, Swasta, Badan Usaha Milik Negara dan Badan Usaha Milik Daerah termasuk kerjasama dengan swasta dengan tempat usaha berupa toko, kios, los dan tenda yang dimiliki/dikelola oleh pedagang kecil, menengah, swadaya masyarakat atau koperasi dengan usaha skala kecil, modal kecil dan dengan proses jual beli barang dagangan melalui tawar menawar;

4) Pusat Perbelanjaan adalah suatu area tertentu yang terdiri dari satu atau beberapa bangunan yang didirikan secara vertikal maupun horizontal, yang dijual atau disewakan kepada pelaku usaha atau dikelola sendiri untuk melakukan kegiatan perdagangan barang;

5) Toko adalah bangunan gedung dengan fungsi usaha yang digunakan untuk menjual barang dan terdiri dari hanya satu penjual;

6) Toko Modern adalah toko dengan sistem pelayanan mandiri, menjual berbagai jenis barang secara eceran yang berbentuk Minimarket, Supermarket, Department Store, Hypermarket ataupun grosir yang berbentuk Perkulakan;

7) Pengelola Jaringan Minimarket adalah pelaku usaha yang melakukan kegiatan usaha di bidang Minimarket melalui satu kesatuan manajemen dan sistem pendistribusian barang ke outlet yang merupakan jaringannya;

Fenomena perkembangan toko modern di Kabupaten Garut cukup dinamis seriring dengan laju pertumbuhan penduduk Kab. Garut, seperti di kutip Media Online Nasional http://nasional.republika.co.id Kabupaten Garut Tidak seperti daerah lain yang menyetop penambahan minimarket, Kabupaten Garut justru menambah kuota minimarket. Hal ini dilakukan agar minimarket di kecamatan tumbuh secara merata, sebelumnya, kuota minimarket di Garut hanya 213 unit sesuai surat keputusan (SK) bupati tahun 2013. Mulai Desember 2015, kuotanya ditambah sebanyak 98 unit, akan tetapi berdasarkan Peraturan Bupati (Perbup) Nomor 3 Tahun 2016, ada aturan yang harus dipenuhi, yaitu persyaratan administrasi tentang jarak antar 
minimarket dengan pasar tradisional. Selain jarak, pengusaha minimarket juga harus menjalin kemitraan dengan masyarakat sekitar.

\section{KERANGKA PEMIKIRAN DAN PEGEMBANGAN HIPOTESIS}

Kotler dan Amstrong mengemukakan definisi bauran pemasaran (marketing mix) sebagai berikut: "Marketing Mix is the set of marketing tools that the firm uses to pursue its marketing objective in the target market". Bauran pemasaran adalah sekumpulan alat pemasaran (marketing mix) yang dapat digunakan oleh perusahaan untuk mencapai tujuan pemasarannya dalam pasar sasaran. Berdasarkan definisi tersebut di atas dapat disimpulkan bahwa marketing mix merupakan unsur-unsur pemasaran yang saling terkait, dibaurkan, diorganisir dan digunakan dengan tepat, sehingga perusahaan dapat mencapai tujuan pemasaran dengan efektif, sekaligus memuaskan kebutuhan dan keinginan konsumen.

Selanjutnya Zeithaml dan Bitner (2001:18-21) mengemukakan konsep bauran pemasaran tradisional (traditional marketing mix) terdiri dari 4P, yaitu product (produk), price (harga), place (tempat/lokasi) dan promotion (promosi). Sementara itu, untuk pemasaran jasa perlu bauran pemasaran yang diperluas (expanded marketing mix for services) dengan penambahan unsur nontraditional marketing mix, yaitu people (orang), physical evidence (fasilitas fisik) dan process (proses), sehingga menjadi tujuh unsur (7P).

Bauran pemasaran jasa yang terdiri dari: price, product, promotion, place, participants, process, dan physical evidence (Pawitra, 1996:42) sedangkan Alma (1992:230), menegaskan bahwa elemen dari marketing mix terdiri dari price, product, promotion, place, personal traits, process, physical evidence.

\section{Harga (Price)}

Stanton (1994:254) mendefinisikan harga sebagai berikut: "Price is amount of money (plus possible some goods) that is needed to acquire some combination of product and it's accompying services." Alma (1992:230) menegaskan bahwa harga berjalan sejajar dengan mutu produk. Apabila mutu produk baik, maka calon mahasiswa berani untuk membayar lebih tinggi. Price also gives a perception of quality (Payne, 1993:150).

\section{1) Produk (product)}

Menurut Stanton (1994: 161), a product is a set of tangible and intangible attributes, including packaging, color, price, manufacturer's prestige, retailer's prestige, and manufacturer's and retailer's services, which the buyer may accept as offering want satisfaction". Jadi produk bukan hanya berbentuk sesuatu yang berwujud saja, tetapi juga sesuatu yang tidak berwujud seperti pelayanan jasa yang dapat dijual, dibeli, dan dapat dimiliki, semuanya digunakan untuk memuaskan kebutuhan dan keinginan dari konsumen.

\section{Promosi (promotion)}

Promosi adalah alat yang digunakan perusahaan jasa untuk berkomunikasi dengan pasar sasaran (Payne, 1993:151). Hal senada dikemukakan oleh Stanton (1994:194), "Promotion is communication about the product or company to the costumers." Promosi merupakan sarana bagi perusahaan untuk memberikan informasi mengenai produk dan manfaatnya kepada pasar sasaran.

\section{Tempat (place)}

Lokasi merupakan keputusan organisasi mengenai tempat untuk beroperasinya semua kegiatankegiatan organisasi. Lokasi sangat berpengaruh terhadap penyampaian produk dan ketepatan pada pasar sasaran. Produk tidak akan mempunyai guna yang lebih bagi konsumen apabila tidak tersedia pada saat dan tempat yang dinginkan. Pemilihan tempat atau lokasi memerlukan pertimbangan yang cermat terhadap beberapa faktor berikut :

a. Akses, misalnya lokasi yang mudah dijangkau sarana transportasi umum.

b. Visibilitas, misalnya lokasi yang dapat dilihat dengan jelas dari tepi jalan.

c. Lalu lintas (traffic), di mana ada dua hal yang perlu dipertimbangkan, yaitu (1) banyaknya orang yang lalu-lalang dapat memberikan peluang besar terjadinya impulse buying, (2) kepadatan dan ke macetan lalu lintas dapat pula menjadi hambatan.

d. Tempat parkir yang luas dan aman.

e. Ekspansi, tersedia tempat yang cukup untuk perluasan usaha di kemudian hari.

f. Lingkungan, yaitu daerah sekitar yang mendukung jasa yang ditawarkan.

g. Persaingan, yaitu lokasi pesaing.

h. Peraturan pemerintah.

\section{Personal Traits}

Personal traits menyangkut perilaku administrator, dosen serta karyawan sebagai penyedia dan pemberi jasa yang dapat berpengaruh terhadap keputusan mahasiswa dalam memilih perguruan tinggi. Personal traits atau Sumber 
daya manusia adalah semua orang atau pelaku yang terlibat dalam proses penyampaian jasa kepada konsumen serta mempengaruhi persepsi konsumen, seperti para personal penyedia jasa, pelanggan dan para pelanggan lain yang terkait dengan jasa tersebut. Hal ini sesuai dengan pendapat yang dikemukan oleh Buchari Alma (2005:37) bahwa "Sumber daya manusia berarti orang yang melayani ataupun yang merencanakan pelayanan terhadap para konsumen". Dari pengertian tersebut dapat disimpulkan bahwa sumber daya manusia adalah semua orang yang dimiliki oleh suatu perusahaan atau lembaga yang terlibat dalam proses penyampaian produk atau jasa kepada konsumen.

\section{Proses (Process)}

Semua kegiatan pekerjaan adalah merupakan proses, meliputi mekanisme pelayanan, prosedur, jadwal kegiatan serta rutinitas penyampaian produk/ jasa pada konsumen. Proses menurut Zeithaml and Bitner (2000:20) adalah "The actual procedures, mechanism, and flow of activities by which the service is delivered the service delivery and operating system".

Proses dalam jasa merupakan faktor utama dalam bauran pemasaran jasa seperti pelanggan jasa akan sering merasakan sistem penyerahan jasa sebagai bagian dari jasa itu sendiri. Selain itu keputusan dalam manajemen operasi adalah sangat penting untuk suksesnya pemasaran jasa. Seluruh aktivitas kerja adalah proses, proses melibatkan prosedurprosedur, tugas-tugas, jadwal-jadwal, mekanisme-mekanisme, aktifitasaktiftas dan rutinitas-rutinitas dengan apa produk (barang atau jasa) disalurkan ke pelanggan. Identifikasi manajemen proses sebagai aktifitas terpisah adalah prasyarat bagi perbaikan jasa. Pentingnya elemen proses ini khususnya dalam bisnis jasa disebabkan oleh persediaan jasa yang tidak dapat disimpan.

\section{Lingkungan fisik (physical evidence)}

Physical evidence perusahaan jasa adalah tempat dimana jasa diciptakan dan dimana pemberi jasa dan konsumen berinteraksi. Physical evidence dapat dibedakan menjadi dua jenis (Payne, 1993:131) yaitu Essential evidence, bagian dari sarana fisik misalnya gedung, peralatan kantor, tata letak dan sebagainya, dan Peripheral evidence, bagian dari sarana fisik misalnya buku pedoman, sertifikat, dan sebagainya.

\section{Pengertian Pasar}

Campbell (1990) mendefinisikan pasar sebagai institusi atau mekanisme di mana pembeli dan penjual bertemu dan secara bersama-sama mengadakan pertukaran barang dan jasa. Selanjutnya Stanton (1996) mendefinisikan pasar sebagai orang-orang yang mempunyai kebutuhan untuk dipuaskan, mempunyai uang untuk dibelanjakan dan kemauan untuk membelanjakan uang.

Kamus Besar Bahasa Indonesia mengistilahkan pasar sebagai tempat orang berjual beli, yang berarti merupakan organisasi dimana penjual dan pembeli dapat saling berhubungan dengan mudah dan dalam Peraturan Presiden Republik Indonesia (Perpres RI) Nomor 112 Tahun 2007 pasar adalah area tempat jual beli barang dengan jumlah penjual lebih dari satu baik yang disebut sebagai pusat perbelanjaan, pasar tradisional, pertokoan, mall, plasa, pusat perdagangan maupun sebutan lainnya.

Pasar modern merupakan pasar dimana penjual dan pembeli tidak bertransaksi secara langsung melainkan pembeli melihat label harga yang tercantum dalam barang, berada dalam bangunan dan pelayanannya dilakukan secara mandiri atau dilayani oleh pramuniaga. Barangbarang yang dijual, selain bahan makanan makanan seperti; buah, sayuran, daging; sebagian besar barang lainnya yang dijual adalah barang yang dapat bertahan lama. Sinaga dalam Aryani (2011) mendefinisikan pasar modern adalah pasar yang dikelola dengan manajemen modern, umumnya terdapat di kawasan perkotaan, sebagai penyedia barang dan jasa dengan mutu dan pelayanan yang baik kepada konsumen (umumnya anggota masyarakat kelas menengah ke atas). Zumrotin (2002) menyatakan pasar modern adalah pasar yang umumnya dimiliki oleh pemodal kuat, mempunyai kemampuan untuk menggaet konsumen dengan cara memberikan hadiah langsung, hadiah khusus, dan juga discountdiscount menarik. Azimah et al (2013) menyatakan pasar modern adalah tempat penjualan barang-barang kebutuhan rumah tangga (termasuk kebutuhan sehari-hari), dimana penjualan dilakukan secara eceran dan dengan cara swalayan (konsumen mengambil sendiri barang dari rak dagangan dan membayar ke kasir).

Pasar modern dapat berbentuk Hypermarket, Supermarket, Minimarket, Department Store maupun perkulakan barang yang dijual memiliki variasi jenis yang beragam. Selain menyediakan barang lokal, pasar modern juga menyediakan barang impor. Barang yang dijual mempunyai kualitas yang relatif lebih terjamin karena melalui penyeleksian yang ketat sehingga barang yang 
tidak memenuhi persyaratan klasifikasi akan di tolak.

\section{Waralaba}

Dalam Peraturan Pemerintah No. 42 Tahun 2007 mengemukakan pengertian Franchise (Warlaba), Franchise (Waralaba) adalah hak khusus yang dimiliki oleh orang perseorangan atau badan usaha terhadap suatu sistem bisnis dengan ciri khas usaha di dalam rangka memasarkan barang dan jasa yang sudah terbukti berhasil dan dapat dimanfaatkan atau dipergunakan oleh pihak lain berdasarkan perjanjian franchise (waralaba).

\section{METODE PENELITIAN}

Dalam pelaksanaan penelitian ini menggunakan jenis penelitian kualitatif dan menggunakan pendekatan deskriftif untuk memperoleh gambaran terhadap lingkungan Toko Modern. Faktor-faktor lingkungan internal dan eksternal kemudian dianalisis dengan menggunakan analisis SWOT untuk mengetahui faktor kekuatan, kelemahan, peluang dan ancaman yang dihadapi. Hasil analisis faktor-faktor berupa konsep bauran pemasaran 7P yang kemudian dapat dijadikan alternatif pemilihan di masa yang akan datang. " Kirik dan Miller (1986:9) menyebutkan bahwa metode penelitian kualitatif adalah tradisi tertentu dalam ilmu pengetahuan sosial yang secara fundamental bergantung daripada pengamatan pada manusia baik dalam kawasannya maupun dalam peristilahannya". (Moleong, 2007:4).

Metode / Teknik Pengumpulan Data adalah Metode Wawancara, Metode Observasi Partisipasi (Participant Oberver), Metode Dokumenter, Metode Penelusuran Online, Survey atau field research, Kuesioner.

Validitas dan Realiabilitas Penelitian Kualitatif: Validitas dan Reliabilitas Penelitian Kualitatif adalah dengan menggunakan Uji Keabsahan Data yang meliputi uji credibility (validitas internal), uni transfarancy (validitas eksternal), dependability (reliabilitas) dan confirmability (objektivitas) (Sugiyono, 2009:459).

Waktu Penelitian / Kajian ini dilaksanakan selama 1 bulan terhitung sejak tanggal 20 Mei s.d. 20 Juni 2017.

\section{HASIL DAN PEMBAHASAN}

Kabupaten Garut sebagaimana Permendagri Nomor 6 Tahun 2008 tentang Kode dan Data Wilayah Administrasi Pemerintahan memiliki luas
307.407 Ha, dengan ibu kota kabupaten berada pada ketinggian 717 mdpl dikelilingi oleh Gunung Karacak (1838 m), Gunung Cikuray (2821 m), Gunung Papandayan (2622 m), dan Gunung Guntur (2249 m) dan secara geografis wilayahnya terletak pada koordinat 6056'49" - 7045'00" Lintang Selatan dan 107025'8" - 10807'30" Bujur Timur dengan batas-batas wilayah:

- Sebelah Utara, berbatasan dengan Kabupaten Bandung dan Kabupaten Sumedang;

- Sebelah Timur, berbatasan dengan Kabupaten Tasikmalaya;

- Sebelah Selatan, berbatasan dengan Samudra Indonesia;

- Sebelah Barat, berbatasan dengan Kabupaten Bandung dan Cianjur.

Secara administratif, sampai tahun 2012, Kabupaten Garut terdiri dari 42 kecamatan, 421 desa, 21 kelurahan, 3.820 RW dan 13.890 RT. Wilayah terluas pada Kecamatan Cibalong mencapai 6,97\% dari wilayah Kabupaten Garut atau seluas $21.359 \mathrm{Ha}$, sedangkan kecamatan Kersamanah merupakan wilayah terkecil dengan luas $1.650 \mathrm{Ha}$ atau $0,54 \%$.

Dalam penyusunan kebijakan perencanaan pembangunan Kabupaten Garut turut memperhatikan arah pembangunan kewilayahan yang telah ditetapkan dalam Rencana Tata Ruang Wilayah (RTRW) Kabupaten Garut Tahun 20112031 sebagai upaya mewujudkan ruang Kabupaten Garut sebagai daerah konservasi yang didukung oleh agribisnis, pariwisata dan kelautan. BerdasarkanRTRW Kabupaten Garut Tahun 20112031, sistem pusat kegiatan Kabupaten terbagi atas

a. Pusat Kegiatan Wilayah promosi (PKWp) adalah kawasan perkotaan yang berpotensi pada bidang tertentu dan memiliki pelayanan skala provinsi atau beberapa kabupaten serta berperan sebagai penyeimbang dalam pengembangan wilayah provinsi, berupa perkotaan Rancabuaya yang berada di kecamatan Caringin;

b. Pusat Kegiatan Lokal (PKL) adalah kawasan perkotaan yang berfungsi untuk melayani kegiatan skala kabupaten atau beberapa kecamatan, terletak di Perkotaan Garut, Perkotaan Pameungpeuk, Perkotaan Cikajang dan Perkotaan Bungbulang.

c. Pusat Kegiatan Lokal Promosi (PKLP) adalah kawasan perkotaan yang berpotensi pada bidang tertentu dan memiliki pelayanan skala kabupaten atau beberapa kecamatan serta berperan sebagai penyeimbang dalam 
pengembangan wilayah kabupaten, terletak di Perkotaan Kadungora; Perkotaan Malangbong; Perkotaan Cibatu; dan Perkotaan Singajaya.

d. Pusat Pelayanan Kawasan (PPK) adalah kawasan perkotaan yang berfungsi untuk melayani kegiatan skala kecamatan, meliputi Perkotaan Cisewu; Perkotaan Caringin; Perkotaan Talegong; Perkotaan Mekarmukti; Perkotaan Pamulihan; Perkotaan Pekenjeng; Perkotaan Cikelet; Perkotaan Cibalong; Perkotaan Cisompet; Perkotaan Peundeuy; Perkotaan Cihurip, Perkotaan Banjarwangi; Perkotaan Cilawu; Perkotaan Bayongbong; Perkotaan Cigedug; Perkotaan Cisurupan; Perkotaan Sukaresmi; Perkotaan Samarang; Perkotaan Pasirwangi; Perkotaan Karangpawitan; Perkotaan Wanaraja; Perkotaan Pangatikan; Perkotaan Sucinaraja; Perkotaan Sukawening; Perkotaan Karangtengah; Perkotaan Banyuresmi; Perkotaan Leles; Perkotaan Leuwigoong; Perkotaan Kersamanah; Perkotaan Cibiuk; Perkotaan Balubur Limbangan; dan Perkotaan Selaawi.

e. Pusat Pelayanan Lingkungan (PPL) adalah pusat permukiman yang berfungsi untuk melayani kegiatan skala antar desa.

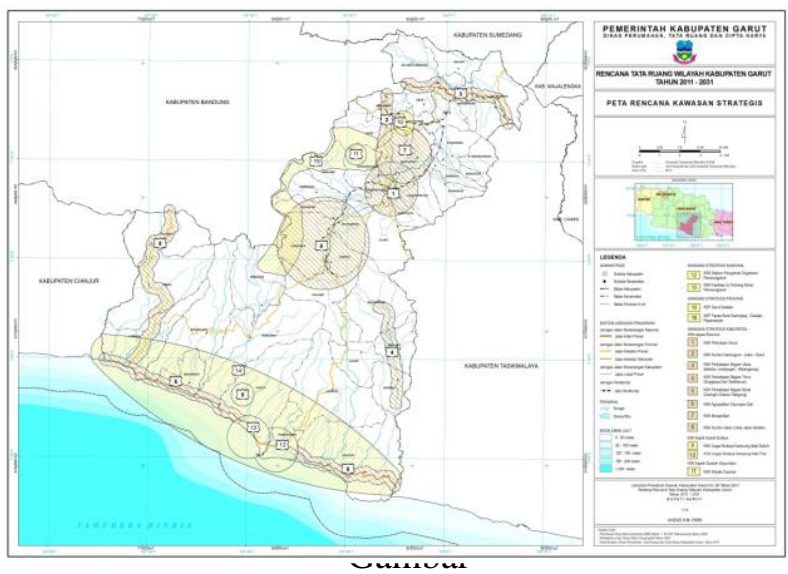

Rencana Kawasan Strategis Wilayah Kabupaten Garut

( Sumber : Perda No. 3 Tahun 2014 Tentang RPJMD Kabupaten Garut 2014-2019 )

Regulasi waralaba / took modern di Kabupaten Garut berdasakan Peraturan Daerah Kabupaten Garut Nomor 3 Tahun 2014 Tentang Rencana Pembangunan Jangka Menengah Daerah Kabupaten Garut Tahun 2014-2019 dan Peraturan Bupati Garut No. 3 Tahun 2016 Tentang Penataan dan Pembinaan Pasar Rakyat, Pusat Perbelanjaan, dan Toko Swalayan.
Dalam upaya penataan dan pembinaan baik Pasar Tradisional, Pusat Perbelanjaan, dan Toko Modern di wilayah Kabupaten Garut guna menumbuhkan iklim kondusif, bermanfaat, serasi, adil dan mempunyai kepastian hukum bagi seluruh warga masyarakat, Pemerintah Daerah Kabupaten Garut telah menetapkan sebelumnya melalui Peraturan Bupati Garut No. 49 Tahun 2012 tentang Penataan dan Pembinaan Pasar Tradisional, Pusat Perbelanjaan, dan Toko Modern. Perbub tersebut telah dicabut dan ditetapkan Peraturan Bupati Garut No. 3 Tahun 2016 Tentang Penataan dan Pembinaan Pasar Rakyat, Pusat Perbelanjaan, dan Toko Swalayan.

Penelitian / kajian ini dilaksanakan dengan mengambil dua sampel lokasi yaitu mini market di daerah Kecamatan Tarogong Kidul dan Kecamatan Cilawu :

1) Nama Mini Market ALFAMART / CV. SOLIHAN SAS JAYA

2) Nama Mini Market ALFAMART OTISTA

Lokasi Pendirian; Pemerintah Kabupaten Garut telah menentukan Lokasi Pendirian Pusat Perbelanjaan dan Toko Modern khusunya Alfamart mengacu pada Rencana Tata Ruang Wilayah (RTRW) Kabupaten Garut Tahun 2011-2031 dan Peraturan Bupati Garut No. 3 Tahun 2016 Tentang Penataan dan Pembinaan Pasar Rakyat, Pusat Perbelanjaan, dan Toko Swalayan. Dari hasil penelitian didapat hasil mengenai lokasi pendirian ke 2 alfamart tersebut telah mengacu pada peraturan tersebut. Tenaga Kerja; 89\% diserap tenaga kerja local untuk Alfamart / CV. SOLIHAN SAS JAYA dan Alfamart OTISTA 33,33\% tenaga kerja local Jam Operasional; telah mengacu pada Peraturan Bupati Garut No. 3 Tahun 2016 yaitu senin-jumat jam 09.00 s.d. 22.00 WIB sedangkan hari minggu/libur 09.00 s.d. 22.00 WIB.

Peraturan Bupati Garut No. 3 Tahun 2016 pasal 15, 16 dan 17 kemitraan Toko Swalayan / Mini Market diperlukan untuk mencapai kesejateraan bersama dan dalam rangka menciptakan hubungan kerjasama yang berkeadilan, saling menguntungkan dan tanpa tekanan antara Pemasok dengan Toko Swalayan, Pemerintah Daerah dapat memfasilitasi kepentingan Pemasok dan Toko Swalayan dalam rangka melakukan kerjasama sebagaimana dimaksud. Kemitraan dengan UMKM belum terjalin sengan baik dengan tidak adanya kemitraan ke dua took modern tersebut.

Pesyaratan Pendirian Mini Market / Toko Swalayan sudah sangat jelas tertuang dalam Peraturan Bupati Garut No. 3 Tahun 2016 Tentang 
Penataan dan Pembinaan Pasar Rakyat, Pusat Perbelanjaan, dan Toko Swalayan dengan memperhatikan; Kepadatan Penduduk, Perkembangan Permukiman Baru, Aksesibilitas Wilayah, Dukungan Infrastruktur, Keberadaan Warung/Toko Tradisional.

Berdasarkan berberapa pernyataan dalam angket / kuisioner terkait perspektif pelayanan dan bauran pemasaran yang diajukan kepada responden sebanyak 100 respoden di sekitar Alfamart Otista dan 100 responden di sekitar Alfamart Cilawu total responden sebanyak 200 orang scbagaimana tersebut diatas, juga dilakukan wawancara tidak terstruktur kepada seluruh responden terkait keberadaan alfamart di kedua lokasi tersebut, dari hasil wawancara dimaksud maka dapat dilihat bahwa kecenderungan dan harapan masyarakat yang dijadikan responden adalah keberadaan alfamart harus dapat memberikan lapangan kerja untuk masyarakat sekitar, tidak menjadi kompetitor pedagang kecil bahkan lebih jauh lagi dapat membina keberadaan warung / toko2 kecil, masyarakat merasa terbantu karena sebenarnya keberadaan alfamat dengan keberagaaman produknya dapat menghemat biaya perjalanan dari pada harus belanja ke pusat kota ataumencari super market yang lebih besar.

\section{SIMPULAN DAN SARAN}

\section{Kesimpulan}

Berdasarkan hasil kajian dan pembahasan

Toko Modern Alfamart Otista dan Alfamart Cilawu, maka dapat disimpulkan sebagai berikut:

1. Lokasi pendirian Toko Moden Alfamart Otista dan Alfamart Cilawu telah sesuai dengan peraturan peundang-undangan yang berlaku namun disetiap kecamatan hendaknya dilakukan penataan lokasi lain sebaran dengan memperhatikan keberadaan pedagangpedagang yang sejenis.

2. Toko Modern Alfamart Otista dan Alfamart Cilawu telah mampu menyerap tenaga kerja lokal lebih dari $80 \%$ dengan minimal pendidikan SMA juga hendaknya dapat merekrut yg berpendidikan di bawah SMA misalnya untuk tugas cleaning service.

3. Toko Modern Alfamart Otista dan Alfamart Cilawu dalam melaksanakan jam operasional kegiatan usahanya sesuai dengan Peraturan Bupati Garut No. 3 tahun 2016 akan tetapi di Alfamart Otista walaupun bukan hari besar keagamaan, libur nasional, tetap mejalankan shif 3 yaitu jam 22 s.d. 06.00.
4. Dalam hal kemitraan dengan UMKM Toko Modern Alfamart Otista dan Alfamart Cilawu belum menjalin kemitraan dengan Usaha Mikro, Kecil dan Menengah (UMKM).

5. Toko Modern Alfamart Otista dan Alfamart Cilawu belum memperhatikan persyaratan pendirian toko modern sesuai dengan peraturan seperti Toko Modern Alfamart Otista dan Alfamart Cilawu yang scharusnya sudah mémperpanjang kembali masa berlaku dan syarat lain yang harus terpenuhi sebuah toko modern, bukan hanya dipenuhi

6. Berdasarkan hasil angket yang disebar kepada konsumen yang sedang berbelanja di Toko Modern Alfamart Otista dan Alfamart Cilawu terkait dengan Pelaksanaan Bauran Pemasaran Jasa Ritel telah memenuhi harapan konsumen walaupun belum optimal pihak pemerintah perusahaan harus terus memperhatikan kualitas pelaynan terutama fasilitas lain yang harus dipenuhi seperti lahar parker, toilet dan mushola.

\section{Saran}

Berdasarkan pembahasan hasil kajian dan kesimpulan yang telah dibuat diatas, maka kami menyarakan :

1. Lokasi : Hendaknya tetap dilakukan penataan lokasi dengan memperhatikan keberadaan pedagang-pedagang lain yang sejenis yang ada di daerah tertentu dalam persyaratan toko modern baru.

2. Tenaga Kerja / SDM LOkal : Hendaknya dapat menyerap tenaga kerja local dengan merekrut SDM yang berpendidikan di bawah SMA misalnya untuk petugas cleaning service dan bagian lain yang memungkinkan.

3. Jam operasional : Hendaknya Peraturan Bupati Garut No. 3 tahun 2016 harus benarbenar diperhatikan karena terkait dengan keamanan dan kesehatan tenaga kerja setiap took modern.

4. Kemitraan dengan UMKM : Hendaknya menjalin kemitraan dengan Usaha Mikro, Kecil dan Menengah (UMKM) agar tercipta saling menguntukan antara pengusaha dengan masyarakat, pengusaha alfamart secara aktif membuka diri untuk kemitraan dan kerjasama dengan UMKM dengan perjanjian kerjasama, seperti usaha bersama dengan metode bagi hasil, atau memilih (komoditi) potensi daerah sebagai pemasok barang yang akan di jual lebih jauh bisa dikembankan konsep bapak angkat persuhaan, untuk perusahaan- 
perusahaan tertentu yang dimungkinkan menjadi mitra kerja perusahaan (alfamart).

5. Persyaratan pendirian toko modern : Hendaknya dilakukukan pengawasan yang lebih intensif dari pemerintah daerah yang memiliki kewenangan dan pengelola toko juga wajib memperhatikan hal ini termasuk masalah masa berlaku ijin pendirian dan persyaratan lain.

6. Untuk meningkatkan kepuasan masyarakat hendaknya diperhatikan masalah Harga yang sesuai dengan harga yang berada di toko sekitar dan Sarana Fisik perlu ditingkatkan khususnya tempat ibadah, toilet dan sarana parkir yang memadai

\section{REFERENSI}

Zithaml, Valarie A dan Bitner, 2000, Service Marketing 2 Edition: IntegratingM Coustumer Focus. New York: Mc. Graw Hill Inc.

Pawitra, T. 2001. Manajeme pemasaran di Indonesta: Masa lampau, kini dan masa mendatang, Majalah Usahawan No. 10 Th. XXX Oktober 2001.

Kotler, Philip \& Armstrong, Gary, 2006. Prinsipprinsip Pemasaran. Edisi Keduabelas. Erlangga. Jakarta

Kotler, Philip, 2000, Manajemen Pemasaran, Edisi Milenium, Jakarta

Kotler, Philip, 1995. Marketing jilid II. Penerbit Erlangga, Jakarta

Philip Kotler and Kevin Lane Keller, Alih Bahasa Benyamin Molan 2007,

Manajemen Pemasaran, Edisi Kedua belas, Jilid 1, PT. Indeks.

Amstrong, Gary. \& Philip Kotler. 1996. Dasardasar Pemasaran. Jilid 1. Alih Bahasa Alexander Sindoro dan Benyamin Molan. Prenhalindo. Jakarta.

Payne, A. 1993, The essence of service marketing, USA: Prentice Hall International (UK) Lid.

Alma, Buchari. 2005. Manajemen Pemasaran dan Pemasaran Jasa. Bandung: Alfabeta.

Asep ST. Sujama. 2005. Paradigma Baru Dalam Manajemen Ritel Modern. Yogyakarta : Graha Ilmu.

Basu Swastha dan Irawan. 2000. Asas-asas Marketing. Yogyakarta: Liberty.

Amir, M. Taufiq.2004. Manajemen Ritel: Panduan Lengkap Pengelolaan Toko Modern. Jakarta: Penerbit PM.
Heizer, Jay \& Barry Render, 2008. Manajemen Operasi (Buku 1 Edisi 9). Salemba Empat, Jakarta.

Chase, 1997. The Knowledge-Based Organization - International Survey, Journal of Knowledge Management, pp. 38-49, September 1997.

Ariani, D. Wahyu. 2009. Manajemen Operasi Jasa. Yogyakarta : Graha Ilmu

Christopher H Lovelock dan Lauren K. Wright, 2007, Manajemen Pemasaran Jasa, Alih bahasa Agus Widyantoro, Cetakan Kedua, Jakarta; PT, INDEKS

Fandy, Tjiptono. 2011. Pemasaran Jasa, Bayumedia, Malang.

Stanton, William J.1991. Prinsip Pemasaran. Erlangga. Jakarta.

Stanton, Wifliam, J, 1994. "Fundamental Of Marketing", thent ed Me Grow, Hill Inc : Singapore.

Sucherly, 2002, Strategi Pemasaran Jasa dalam Meningkatkan Keunggulan Bersaing, Jurnal Bisnis dan Manajemen

Campbell, R. McConnell and Stanley L. Brue. 1990. Economics: Principles, Problems andPolicies. McGraw-Hill Publishing Company

Yuyus Suryana dan KartibBayu. 2011, Kewirauasahaan: Pendekatan Karakteristik Wirausahawan Sukses. Jakarta: Kencana.

Zumrotin KS, 2002, Pola Keterkaitan Pasar Modern Dengan Pasar Swalayan, Diklat Manajemen Pasar Daerah, Badan Pendidikan dan Pelatihan Departemen Dalam Negeri.

Undang-Undang Republik Indonesia Nomor 28 Tahun 2009 Tentang Pajak Daerah dan Retribusi Daerah

Peraturan Presiden No. 112 Tahun 2007 Penataan dan Pembinaan Pasar Tradisional, Pusat Perbelanjaan Dan Toko Modern

Peraturan Menteri Perdagangan RI Nomor 70-/MGAD/PER/12/2013 Tentang Pedoman Penatsan Dan Pembinaan Pasar Tradicional Pusat Perbelanjaan dan Toko Modern.

Peraturan Menteri Perdagangan (Permendag) No. 56/2014 tentang Pedoman Penataan dan Pembinaan Pasar Tradisional, Pusat Perbelanjaan, dan Toko Modern.

Perda No 3 Tahun 2014 RPJMD 2014-2019

Peraturan Bupati Garut Nomor 3 Tahun 2016 Tentang Penataan dan Pembinaan Pasar Rakyat, Pusat Perbelanjaan dan Toko Swalayan

http://www.garutkab.go.id 
https://garutkab.bps.go.id

https://www.minimarketrak.com

http://nasional.republika.co.id

Laporan Dinas Penanaman Modal dan Perizinan Terpadu Kabupaten Garut 2017

Majalah SWA No. 02/XX/21 Januari- 4 Februari 2004,

Jurnal Penelitian Humaniora, Vol. 19. No.1, April 2014: 24-35 Implementasi Kebijakan Perencanaan Penataan Toko Modern Berjaringan Nasional Di Kabupaten Sleman Dalam Studi Ekonomi Politik, Ita Mutiara Dewi, FIS Universitas Negeri Yogyakarta

Dampak Keberadaan Pasar Modem Terhadap Usaha Ritel Koperasi/Waserda Dan Pasar Tradisional, Agus Susilo, Taufik, ISSN: 1979-6889

Jumal Riptek Vol.5 No.1 Tahun 2011, Hal.: 31 -43 Analisis Dampak Usaha Ritel Modern Terhadap Usaha Ritel Tradisional (Studi Kasus Di Wilayah Kecamatan Gunungpati, Mijen, Tembalang, Dan Banyumanik) Wyati Saddewisasi, Teguh Ariefiantoro, Aprih Santose.

Dampak Keberadaan Indomaret Terhadap Kondisi Sosial Ekonomi Pedagang Pasar Tradisional Di Kelurahan Terjun Kecamatan Medan Marelan. Ok. Laksemana Lufti.

Jurnal Ekonomi MODERNISASI Fakultas Ekonomi- Universitas Kanjuruhan Malang http://ejournal.ukanjuruhan.ac.id Dampak Keberadaan Pasar Modem Terhadap Kinerja Pedagang Pasar Tradisional Di Wilayah Kabupaten Malang, Endi Sarwoko 